\title{
Harm Avoidance, Anxiety, and Response to Novelty in the Adolescent S-100 $\beta$ Transgenic Mouse: Role of Serotonin and Relevance to Down Syndrome
}

\author{
Kimberly Bell', David Shokrian', Carl Potenzieri' and Patricia M Whitaker-Azmitia*,I \\ 'Program in Biopsychology, Department of Psychology, State University of New York, Stony Brook, NY, USA
}

\begin{abstract}
$\mathrm{S}-100 \beta$ is an astroglial-derived protein, which plays a role in brain development and maintenance, and is known to play a specific role in the regulation of growth of the serotonergic neuronal system. In humans, the gene for $\mathrm{S}-100 \beta$ is found on chromosome 21 , within the region that is considered important for the phenotype of Down syndrome (DS). Thus, we have been studying a model of DS, the S- I00 $\beta$ transgenic mouse. In the current study, we have examined anxiety and responses to novelty in adolescent (60-90 days) animals, at a time when we have shown the animals to be relatively lacking in serotonin innervation, compared to their CD-I nontransgenic controls. In a test for approach/avoidance, the light/dark test, the $\mathrm{S}-100 \beta$ transgenic mice animals showed no differences from control CD-I mice. However, in the hole-board test for exploratory behavior, the S-100 $\beta$ animals were found to be less responsive to the inhibiting effects of the serotonin receptor 5-HTIA agonist, buspirone. Three tests were used to measure response to novelty. In the open field, the S$100 \beta$ animals showed greater activity longer than the control animals, and in the Y-maze test, the $\mathrm{S}$ - $100 \beta$ animals spent more time in the novel arm. In a test for novelty-induced gnawing, the $\mathrm{S}-100 \beta$ animals were also more active than control animals. All of these suggest that the S-100 $\beta$ transgenic mice are slower to habituate to novelty than control animals. Finally, we tested the animals in a new procedure that we are proposing as a test for harm avoidance. In this apparatus, the S-100 $\beta$ animals showed more approaches to a novel and potentially harmful object than the control mice did. These results are discussed in reference to the known lack of serotonin in the animals, and to the behavioral phenotype of DS.
\end{abstract}

Neuropsychopharmacology (2003) 28, I810-1816, advance online publication, 30 July 2003; doi: I0.1038/sj.npp. 1300242

Keywords: S-100 $\beta$; Down syndrome; novelty; anxiety; harm avoidance; buspirone

\section{INTRODUCTION}

$\mathrm{S}-100 \beta$ is an astroglial-derived calcium-binding protein with many diverse effects on the development and maintenance of the central nervous system (Donato, 2001). Examples of S-100 $\beta$ actions include roles in synaptogenesis (Mazer et al, 1997; Wilson et al, 1998), dendritic development (WhitakerAzmitia et al, 1997; Yan et al, 1997), and apoptosis (Huttunen et al, 2000; Ahlemeyer et al, 2000; Brewton et al, 2001) as well as a specific role as a neurotrophic factor for serotonergic neurons (Azmitia et al, 1990; Liu and Lauder, 1992; Whitaker-Azmitia, 2001). Interestingly, S$100 \beta$ is found in humans on chromosome 21 within what is referred to as the obligate region for Down syndrome (DS)

*Correspondence: Dr PM Whitaker-Azmitia, Program in Biopsychology, Department of Psychology, State University of New York, Stony Brook, NY I 1794-2500, USA, Tel: + | 631 -632 9899, Fax: + | 63| 632 7876, E-mail: patricia.whitaker@sunysb.edu

Received I 8 November 2002; revised 10 March 2003; accepted II April 2003

Online publication: 22 May 2003 at http://www.acnp.org/citations/ Npp522214/default.pdf
(Allore et al, 1988), and levels of S-100 $\beta$ are in fact increased in the brain (Royston et al, 1999) and blood (Kato et al, 1990) of subjects with DS. Thus, animals that overexpress this protein may be useful as a model for DS.

The current study looks at some behavioral consequences to such an overexpression, in an S-100 $\beta$ transgenic CD-1 mouse. The behaviors being studied focus on emotional responses to the environment and include response to novelty, approach/avoidance, and harm avoidance. Children with DS are known to not habituate to novelty and to show more impulsivity and less behavioral inhibition (or harm avoidance) than unaffected children. Since $S-100 \beta$ is a serotonergic growth factor, and serotonin is altered in DS, the study also looks at how the animals respond to a serotonin 5-HT1A receptor agonist, buspirone, in the holeboard test of anxiolytic activity.

\section{MATERIALS AND METHODS}

\section{Animals}

S- $100 \beta$ mice and their CD-1 congenic controls are those originally described by Friend et al, 1992 and are bred in 
our facilities at SUSB. The animals are maintained on a $12-\mathrm{h}$ light/dark cycle with free access to water and standard laboratory mouse chow. The animals are weaned at postnatal day (PND) 21, and maintained four to a cage until tested at PNDs 60-90. No animal was tested in more than one paradigm, and littermates were not used in the same paradigm, to preclude the effects of litter. All testing took place between 1000 and 1200, with the exception of the second half of the Y-maze testing, which took place between 1300 and 1500 .

\section{Behaviors}

Light/dark. Animals were tested in a light-dark box constructed of wood by the shops here at SUNYSB. The box is made up of two identical chambers $(20 \mathrm{~cm} \times 20 \mathrm{~cm})$ with a $5 \mathrm{~cm} \times 5 \mathrm{~cm}$ opening in between. One chamber is enclosed entirely, the dark side, and the other is open to ambient room light, the light side. Animals were removed one at a time from their home cage, and placed immediately into the light side. Time spent in the dark (in seconds), latency to enter the dark, and number of entries into the dark were recorded for each animal for $4 \mathrm{~min}$. Animals were scored by three blind raters during the test period. Eight animals were tested from each group.

Hole board. The hole-board apparatus consists of a $26 \mathrm{~cm} \times 52 \mathrm{~cm}$ platform elevated $12 \mathrm{~cm}$ above a floor, with walls $20 \mathrm{~cm}$ high. The platform is divided into four quadrants, and each quadrant contains four square holes $2.2 \times 2.2 \mathrm{~cm}$ placed symmetrically. At $30 \mathrm{~min}$ after an intraperitoneal injection of saline or the 5-HT1A receptor agonist buspirone $(0.2,0.4,0.8 \mathrm{mg} / \mathrm{kg})$ animals were placed into the center of the apparatus, and allowed to explore freely for $4 \mathrm{~min}$. The number of head dips (defined as placing head into a hole) and number of switches between quadrants (defined as placing front paws over a quadrant line) are recorded by blind raters, viewing videotapes. Five animals were used at each dose, from each group (ie 40 animals).

Open field. The open field apparatus is a commercially manufactured animal activity monitoring system (Harvard Apparatus) comprised of an open arena $(45 \mathrm{~cm} \times 45 \mathrm{~cm})$ with eight laser beams, $5 \mathrm{~cm}$ apart, crossing in each dimension. Animals were removed from their home cage and immediately placed into the arena and beam crossings automatically reported for $5 \mathrm{~min}$. Eight animals from each group were tested.

Novel/arm Y-maze. Animals were tested in a standard Ymaze apparatus, consisting of wood and painted black. Each arm measures $36 \mathrm{~cm} \times 16 \mathrm{~cm}$, with walls $32 \mathrm{~cm}$ high. On the first trial, one of the arms was partitioned off. The animals were removed from their home cage and immediately placed into the end of one arm (designated the 'start' arm) and allowed to explore the start arm and the 'other' arm freely for $10 \mathrm{~min}$. The animals were returned to their home cage, and retested $3 \mathrm{~h}$ later. During the second test period, which lasted $5 \mathrm{~min}$, the partition was removed, such that the animals could explore all three arms. Animals were scored for the amount of time spent in each arm, and the number of times an animal entered an arm, defined to be when the front and hind paws are placed into an arm. Eight animals were tested in each group. Three blind raters scored the animals.

Gnawing on inedible objects. Novel inedible objects placed into the home cage of mice can induce gnawing of the object (Hennessy and Foy, 1987). To test this response in the animals, a cardboard tube was placed into each cage for a 1week period, and the weight of the tube was determined before and after exposure to the animals. Six test cages of each animal type were examined. Final results are expressed as weight in grams.

Harm avoidance. The animals were tested in an apparatus constructed in the shops at SUSB. The apparatus consists of an open field measuring $45 \mathrm{~cm} \times 45 \mathrm{~cm}$, with walls $20 \mathrm{~cm}$ high. One corner of the apparatus is designated as the novel box $(5 \mathrm{~cm})$ and is the corner into which the harmful/novel object is placed. The floor is marked with concentric semicircles from that corner, $10 \mathrm{~cm}$ apart. The harmful/ novel object is comprised of four round $(1.5 \mathrm{~cm})$ metallic 'jingle' bells on a $20 \mathrm{~cm}$ long string hanging from an apparatus that moves the bells slowly (once per second) up and down from a height of $10 \mathrm{~cm}$ above the floor down to $1 \mathrm{~cm}$ above the floor. Thus, the apparatus has visual and auditory novelty, and comes close enough to the floor so that it can contact an animal in its path. Animals were placed into the opposite corner of the open field and recorded with a Sony Sureshot digital camera suspended above the apparatus, for $2 \mathrm{~min}$ and the tapes were viewed by at least four raters, and scored for: number of entries into the novel box (defined to be placing the front paws within the novel box), number of contacts with object, number of lines crossed, number of times running through at least two lines directly at the novel object, and number of times rearing against the wall. Also, the animals were scored (in seconds) for time spent within $25 \mathrm{~cm}$ of the object. Since the novel object was suspended by a string, contact with it did not actually hurt an animal. Eight animals of each group were tested.

Statistics. All data were analyzed for significance using ANOVA with repeated measures or $t$-test for independent variables with the SPSS 8.0 program for Windows.

\section{RESULTS}

\section{Anxiety}

Light/dark. A repeated-measures ANOVA for the time spent in light with day as a within-subjects factor and group as a between-subjects factor revealed an effect of day $(\mathrm{F}(1,10)=24.025, p<0.01)$, but not an effect of group or group-by-day interaction. A similar analysis for switches between light and dark revealed an effect of day $(\mathrm{F}(1,10)=51.825, p<0.001)$, but no effect of group or group by day. There was no effect of day, group, or group by day on latency to leave the light. These data are shown in Figure 1. 

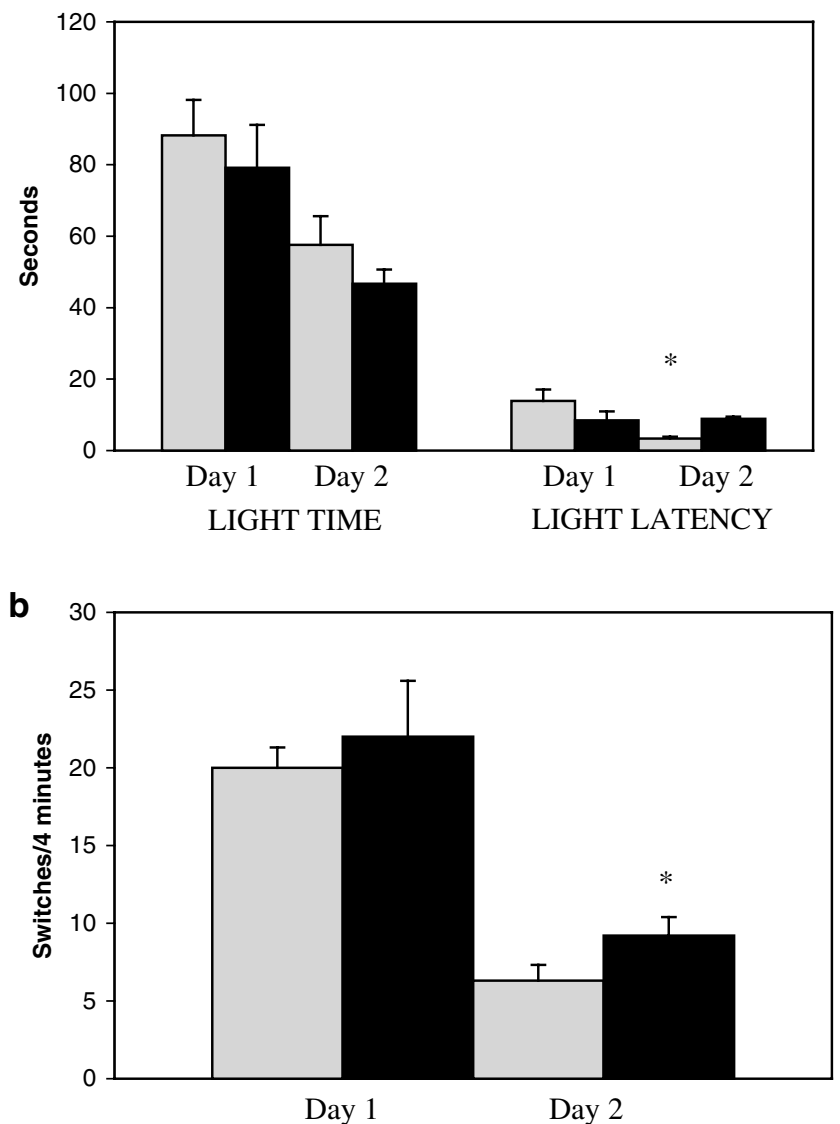

Figure I Light/dark test. (a) Time spent in the light half of the box and time to leave (latency) the light half in control CD-I mice (gray) and S$100 \beta$ mice (black) on 2 days of testing. There were no significant differences between groups on time spent in the light. However, both groups showed a significant decrease in time spent in the light on Day 2 $(p<0.0$ I) (b) Number of times mice switched from one-half of the box to the other. There were no significant differences between groups, but a significant effect of day was present $(p<0.00 \mathrm{I})$.

Hole-board test. Neither the number of head dips $(\mathrm{F}(1,9)=1.025, p>0.05)$ nor the switching between quadrants $(\mathrm{F}(1,9)=1.585, p>0.05)$ showed a significant group effect at baseline. However, the repeated-measures ANOVA showed a significant group-by-dose effect for head dips at $0.2 \mathrm{mg}(\mathrm{F}(1,9)=5.173, p<0.05)$ and switches at $0.2 \mathrm{mg}$ $(\mathrm{F}(1,9)=5.071, \quad p<0.05) \quad$ and $0.4 \mathrm{mg} \quad(\mathrm{F}(1,9)=6.657$, $p<0.05)$ of buspirone. The data are shown in Figure 2.

\section{Response to Novelty}

Open field activity. The repeated-measures ANOVA with minute as a within-subjects factor and group as a betweensubjects factor revealed an effect of time $(\mathrm{F}(1,4)=59.291$, $p<0.0001)$ and group by time $(\mathrm{F}(1,4)=6.601, p<0.001)$. These data are given in Figure 3.

Y-maze/novel arm. Since arm entries are not independent, only novel arm time was compared across groups. The CD-1 control mice spent significantly less time in the novel arm than the $S-100 \beta$ animals did $(F(1,9)=13.031, p<0.01)$. These data are given in Figure 4. a
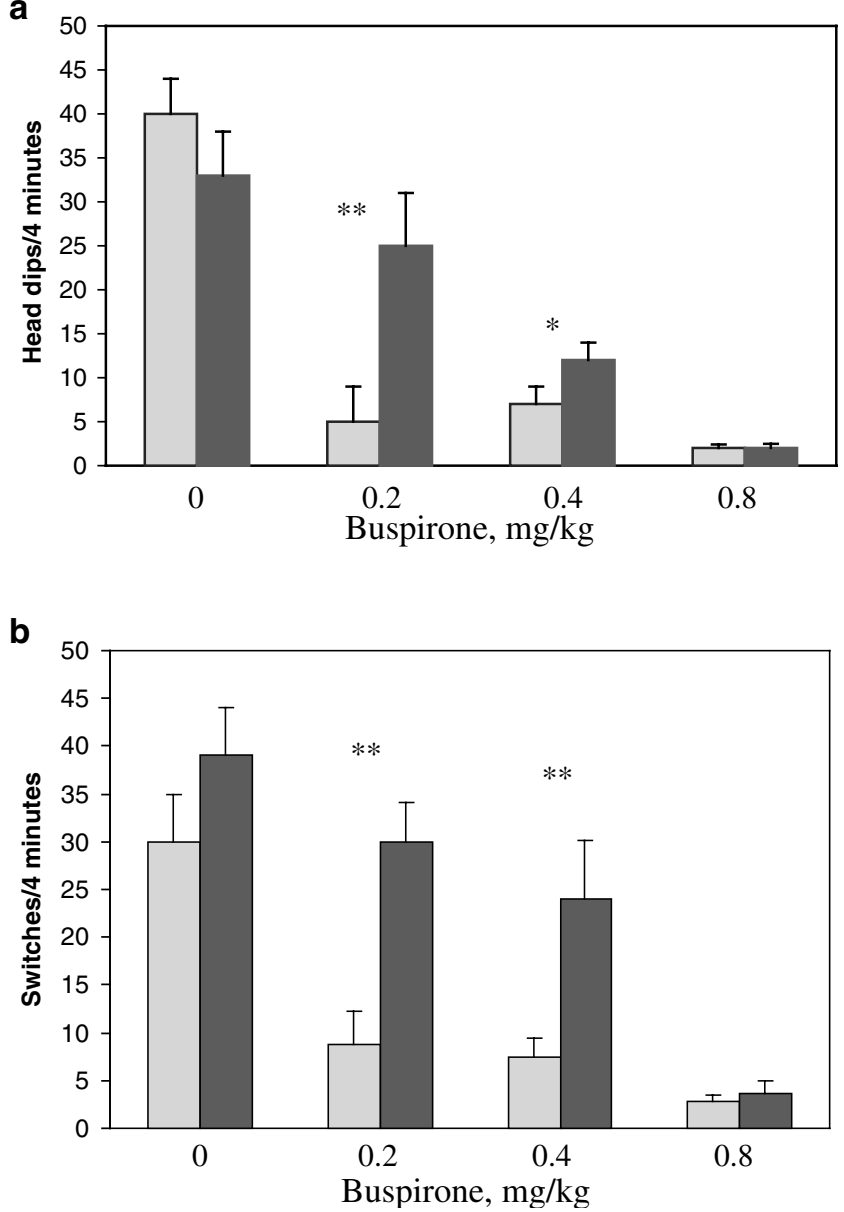

Figure 2 Hole-board test of anxiolytic activity in CD-I mice (gray) and $\mathrm{S}-100 \beta$ transgenic mice (black). (a) Head dips, in response to the 5-HTIA agonist, buspirone. There were no significant differences between the two groups, without saline. However, the CD-I animals showed a greater inhibitory response to the drug than the $\mathrm{S}-100 \beta$ mice, at a dose of $0.2 \mathrm{mg} /$ $\mathrm{kg}\left({ }^{*} p<0.05\right)$. (b) Number of switches between quadrants in response to buspirone. Again, without drugs, there were no significant differences between the animals. However, at doses of 0.2 and $0.4 \mathrm{mg} / \mathrm{kg}$, the CD- I animals were significantly more inhibited in their responses $(* p<0.05)$.

Gnawing of inedible objects. The cardboard tubes left in the cages of the $S-100 \beta$ animals showed significantly more loss than those left in the cages of the control animals $(3.52 \pm 0.05$ vs $1.85 \pm 0.37 ; p<0.001)$. These data are shown in Figure 5.

\section{Harm Avoidance}

Using an independent $t$-test, all the measures recorded showed significant differences. Thus, the CD-1 animals entered the novel box on fewer occasions than the S-100 $\beta$ animals $(1.0 \pm 0.3$ vs $2.8 \pm 0.5 ; p<0.01)$, made fewer contacts $(0.2 \pm 0.1$ vs $2.3 \pm 0.2 ; p<0.001)$ and fewer runs through the center of the box towards the object $(0.9 \pm 0.6$ vs $8.4 \pm 1.7 ; p<0.001)$. The CD-1 animals also showed significantly less rearing against the wall $(8.4 \pm 1.7 \mathrm{vs}$ $25.4 \pm 1.6 ; p<0.001)$ and fewer line crossings $(61.0 \pm 4.1 \mathrm{vs}$ $17.3 \pm 3.2 ; p<0.001)$. All these results are given in Figure 6 . In addition, the S-100 $\beta$ animals spent more time within 


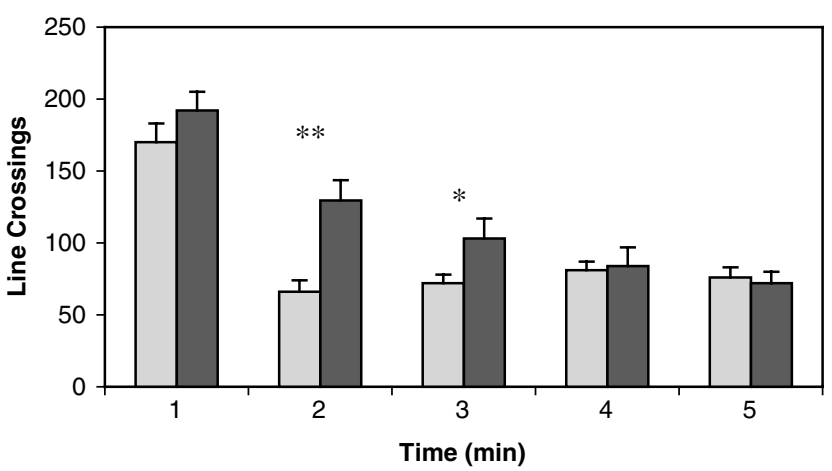

Figure 3 Number of lines crossed in the open field by CD-I mice (gray) and S-100 $\beta$ mice (black). In the first minute and the last two minutes of testing, the two groups of mice showed no significant difference. However, in the second and third minutes of recording, the CD-I mice showed significantly fewer line crossings than the $\mathrm{S}-100 \beta$ mice $(* p<0.05$, *** $<0.01$ )

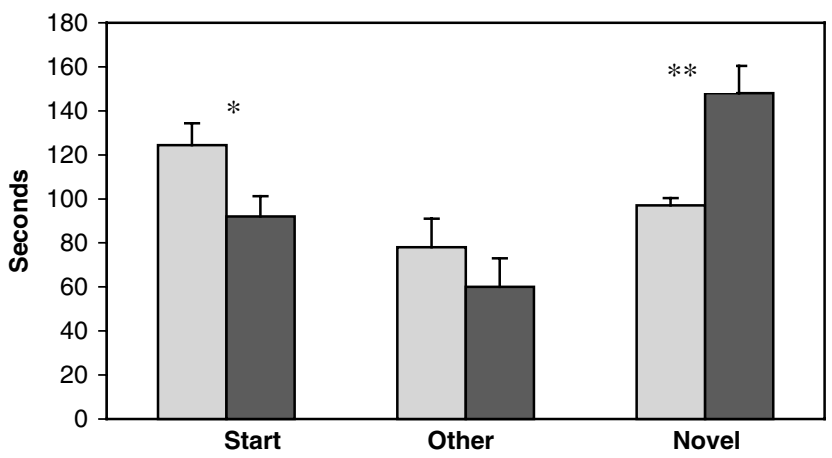

Figure 4 Time spent in the arms of the Y-maze, for CD-I (gray) and S$100 \beta$ (black) mice. The CD-I mice spent significantly less time in the novel arm than the $\mathrm{S}-\mathrm{I} 00 \beta$ animals did (** $p<0.0 \mathrm{I})$.

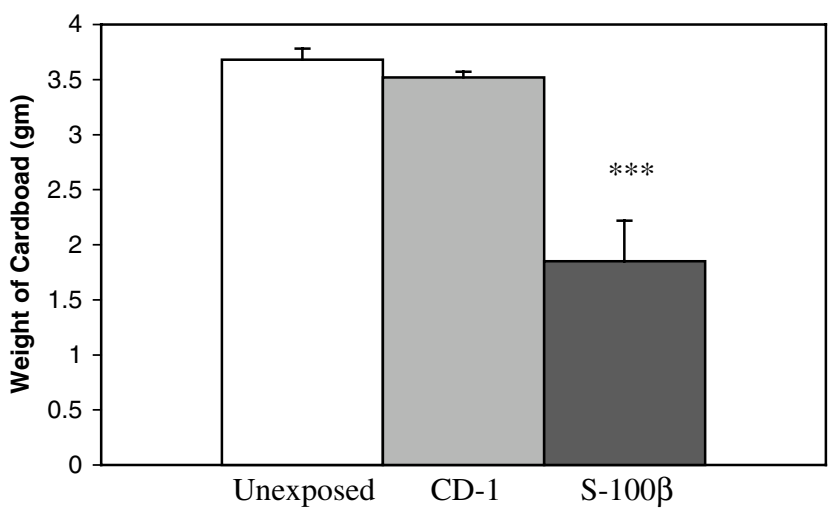

Figure 5 Weight of cardboard left in the cages of CD-I mice (gray), S$100 \beta$ mice (black), or the cardboard before exposure to mice (white). The CD-I mice did not significantly gnaw the inedible object, while the $\mathrm{S}-100 \beta$ mice did $(* * * p<0.001)$.

$25 \mathrm{~cm}$ of the object than did the control animals $(24.6 \pm 2.1$ vs $11.3 \pm 4.3 \mathrm{~s}, p<0.01)$.

\section{DISCUSSION}

S-100 $\beta$ transgenic mice have been studied in order to determine what contribution the overexpression of S-100 $\beta$ might make to the phenotype of DS, although they represent overexpression of only one of the possible 200 genes, which may actually be overexpressed in DS. However, since S-100 $\beta$ is known to play a role in brain development, maintenance, and degeneration, it makes a good candidate, and earlier studies have shown a significant role for this gene in the DS phenotype. For example, previous behavioral studies with S$100 \beta$ transgenic mice have found altered hippocampal functioning as evident in impairments in spatial and nonspatial memory (Roder et al, 1996; Gerlai and Roder, 1995, 1996; Whitaker-Azmitia et al, 1997), modeling some of the cognitive deficits of DS. Also, the animals have been found to have altered development of dendrites and serotonin terminal density in the hippocampus (WhitakerAzmitia et al, 1997), which can also be observed in postmortem DS brains (Becker et al, 1986; Yates et al, 1986; Takashima et al, 1994; Seidl et al, 1999).

The behaviors described in the current study encompass a spectrum of behaviors, all of which can be characterized as a response to novelty in the environment. These behaviors are of interest both because of their possible occurrence in DS and also because of their known relation to the serotonergic system. Children with DS have long been known to display a particular temperament or behavioral phenotype (Gibbs and Thorpe, 1983). Broadly speaking, this
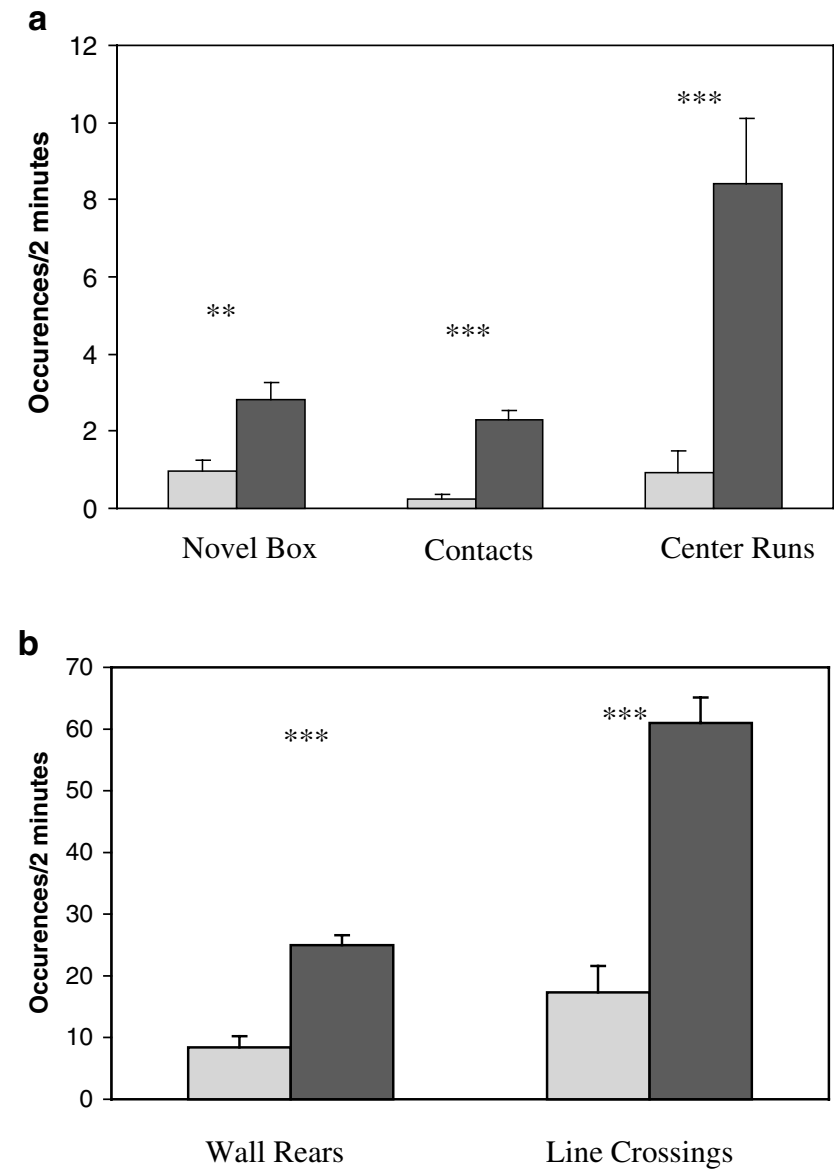

Figure 6 Measures of harm avoidance in CD-I mice (gray) and S-100 $\beta$ mice (black). All measures showed a significant difference. (a) The CD-I mice entered the novel box less often, made fewer contacts with the harmful object, and showed fewer 'center runs' than the S-100 $\beta$ mice. (b) The CD-I mice showed fewer rears against the wall and line crossings than the $\mathrm{S}-\mathrm{I} 00 \beta$ animals (** $p<0.0 \mathrm{I}$, *** $p<0.00 \mathrm{I}$ ). 
behavioral phenotype can be divided into two characteristic areas: decreased harm avoidance and increased response to novelty. In general, children with DS are not considered to be more anxious than non-DS children.

In the light/dark approach/avoidance conflict paradigm, the $S-100 \beta$ animals did not appear to differ from the control animals. This is consistent with the findings in children with DS, in whom anxiety is not a prominent feature, although it may occur more in younger children (Myers and Pueschel, 1991) or children who are less severely cognitively impaired (La Malfa et al, 1997). The hole-board test of exploratory behavior did not show differences between the two groups at baseline. However, the S-100 $\beta$ animals showed a blunted response to the 5-HT1A agonist buspirone. Unlike classic anxiolytics, such as benzodiazepines, 5-HT1A agonists are known to inhibit head dips in mice and our dose-responses in the CD-1 mice are similar to those reported for 1CR mice (Tsuji et al, 2000). The blunted response of the S-100 $\beta$ animals to a 5-HT1A agonist was unexpected. At this age, the $S-100 \beta$ animals have been found to have a reduced density of serotonin terminals in the hippocampus, so that a supersensitive receptor response might have been expected. The current findings suggest that disruption of the serotonin system might be more global than merely changes in the serotonin neuron itself. This could suggest that the S$100 \beta$ animals are more resistant to the behavioral inhibiting effects of serotonin. In a post-mortem study of DS, 5-HT1A receptors have indeed found to be decreased (Bar-Peled et al, 1991). It is also possible that these results are indicative of a very much higher rate of exploratory response in the $\mathrm{S}-100 \beta$ mice than in the control mice, and that the apparent similar responses in baseline are, in fact, a ceiling effect.

At least three behaviors may indicate increased response to novelty: delayed habituation in the open field, increased gnawing response to novel inedible objects and time spent in the novel arm of the Y-maze. S-100 $\beta$ animals have previously been shown to have delayed habituation (Gerlai and Roder, 1995). DS children have also been shown to be slow to habituate to repeated stimuli. Event- and sensoryrelated potentials have been used to study this phenomenon for over 30 years (Barnet and Lodge, 1967; Dustman and Callner, 1979; Schafer and Peeke, 1982; Kaneko et al, 1996; Seidl et al, 1999). These findings are unique to DS and are not observable in all forms of mental retardation (Karrer et al, 1998). Delayed habituation can even be found in utero (Hepper and Shahidullah, 1992). A PET study of glucose utilization has also shown increased response to repeated stimuli in DS (Schapiro et al, 1987) and it has been suggested that failure to habituate to novelty correlates with impaired intellectual functioning in DS (Berg and Sternberg, 1985). Thus, the findings of increased response to novelty in S-100 $\beta$ transgenic mice are in agreement with findings in DS.

The commonly accepted image of children with DS is that they have a friendly outgoing temperament and that they approach strangers easily, suggestive of lack of fear. Even when presented with fearful expressions in caregivers, DS children do not show fear and respond with a generally positive affect (Knieps et al, 1994). DS children show less behavioral inhibition (Nygaard et al, 2002) and more impulsivity (Pueschel et $a l, 1991$ ) and compulsive behaviors
(Kopp et al, 1983; Evans and Gray, 2000). These behaviors-impulsivity and lack of fear-are one extreme of the harm avoidant dimension of Cloninger's Tridimensional theory of personality (Cloninger, 1987). In order to test the animals for harm avoidance changes, we have used a test apparatus wherein the animal could passively avoid a potentially harmful object. The CD-1 animals spent less time within the half of the apparatus containing the object, rarely entered the novel box, and no animal was contacted more than once by the object. Conversely, the S-100 $\beta$ animals spent more time closer to the object, directly entering into the novel box, and seven out of the eight animals tested made contact more than once with the object. All this suggests a diminished harm avoidance in the S-100 $\beta$ animals. The increases in wall rearing may be viewed as failure to habituate to novelty; however, the center runs observed in the apparatus are a relatively unreported behavior. It is possible that this behavior is a form of stereotypy and requires further study. Children with DS also have been shown to display stereotypic motor behaviors (Haw et al, 1996).

In summary, the $\mathrm{S}-100 \beta$ animals showed less habituation to novelty and less harm avoidance, with no apparent change in anxiety. At this age, the $\mathrm{S}-100 \beta$ mice have been found to have significantly fewer serotonin terminals in temporal lobe structures than the CD-1 control mice and thus, the behavioral changes may be due, at least in part, to the lowered levels of serotonin. Serotonin lesions decrease habituation in the open field in rats (Bidzinski et al, 1998) and treatment with serotonergic agonists increase habituation, as measured by prepulse inhibition (Dulawa and Geyer, 2000). The harm avoidance finding may also be related to the low levels of serotonin. Cloninger's (1987) theory of the harm avoidance/impulsivity spectrum of personality traits is proposed to be related to levels of serotonin, wherein high levels of serotonin are related to high levels of harm avoidance and low levels of serotonin are related to impulsivity (for reviews, see Hollander and Rosen, 2000; Oquendo and Mann, 2000). In animal studies, lesion of serotonergic pathways leads to a loss of behavioral inhibition (Geyer et al, 1976). Thus, both the behavioral phenotypes we have found may be at least in part related to the low levels of serotonin in the animals.

In conclusion, the $\mathrm{S}-100 \beta$ transgenic mouse may be a useful model for DS, as it mimics much of the behavioral phenotype, particularly those associated with loss of serotonin.

\section{ACKNOWLEDGEMENTS}

The technical assistance of Alice Borella and Sharon Fricker is gratefully acknowledged. We are also grateful to the students who participated as raters: Nick Misiti, Svetlana Rosis, Adam Litroff, and Raquel Aponte. The statistical assistance of Dr Brenda Anderson is also appreciated. This work is funded by a grant from NINDS - RO1 NS 042555.

\section{REFERENCES}

Ahlemeyer B, Beier H, Semkova I, Schaper C, Krieglstein (2000). S100beta protects cultured neurons against glutamate- and 
staurosporine-induced damage and is involved in the antiapoptotic action of the $5 \mathrm{HT}(1 \mathrm{~A})$-receptor agonist, Bay $\mathrm{x} 3702$. Brain Res 858: 121-128.

Allore R, O'Hanlon D, Price R, Neilson K, Willard HF, Cox DR et al (1988). Gene encoding the beta subunit of S100 protein is on chromosome 21: implications for Down syndrome. Science 239: 1311-1313.

Azmitia EC, Dolan K, Whitaker-Azmitia PM (1990). S-100B but not NGF, EGF, insulin or calmodulin is a CNS serotonergic growth factor. Brain Res 516: 354-356.

Bar-Peled O, Gross-Isseroff R, Ben-Hur H, Hoskins I, Groner Y, Biegon A (1991). Fetal human brain exhibits a prenatal peak in the density of serotonin 5-HT1A receptors. Neurosci Lett 127: 173-176.

Barnet AB, Lodge A (1967). Click evoked EEG responses in normal and developmentally retarded infants. Nature 214: 252-255.

Becker LE, Armstrong DL, Chan F (1986). Dendritic atrophy in children with Down's syndrome. Ann Neurol 20: 520-526.

Berg CA, Sternberg RJ (1985). Response to novelty: continuity versus discontinuity in the developmental course of intelligence. Adv Child Dev Behav 19: 1-47.

Bidzinski A, Siemiatkowski M, Czlonkowska A, Tonderska A, Plaznik A (1998). The effect of serotonin depletion on motor activity habituation, and $\left[{ }^{3} \mathrm{H}\right]$ muscimol binding in the rat hippocampus. Eur J Pharmacol 353: 5-12.

Brewton LS, Haddad L, Azmitia EC (2001). Colchicine-induced cytoskeletal collapse and apoptosis in N-18 neuroblastoma cultures is rapidly reversed by applied S-100beta. Brain Res 912: 9-16.

Cloninger CR (1987). A systematic method for clinical description and classification of personality variants. A proposal. Arch Gen Psychiatry 44: 573-588.

Donato R (2001). S100: a multigenic family of calcium-modulated proteins of the EF-hand type with intracellular and extracellular functional roles. Int J Biochem Cell Biol 33: 637-668.

Dulawa SC, Geyer MA (2000). Effects of strain and serotonergic agents on prepulse inhibition and habituation in mice. Neuropharmacology 39: 2170-2179.

Dustman RE, Callner DA (1979). Cortical evoked responses and response decrement in nonretarded and Down's syndrome individuals. Am J Ment Defic 83: 391-397.

Evans DW, Gray FL (2000). Compulsive-like behavior in individuals with Down syndrome: its relation to mental age level, adaptive and maladaptive behavior. Child Dev 71: 288-300.

Friend WC, Clapoff S, Landry C, Becker LE, O'Hanlon D, Allore RJ et al (1992). Cell-specific expression of high levels of human S100 beta in transgenic mouse brain is dependent on gene dosage. J Neurosci 12: 4337-4346.

Gerlai R, Roder J (1995). Abnormal exploratory behavior in transgenic mice carrying multiple copies of the human gene for S100 beta. J Psychiatry Neurosci 20: 105-112.

Gerlai R, Roder J (1996). Spatial and nonspatial learning in mice: effects of S100 beta overexpression and age. Neurobiol Learn Memory 66: 143-154.

Geyer MA, Puerto A, Menkes DB, Segal DS, Mandell AJ (1976). Behavioral studies following lesions of the mesolimbic and mesostriatal serotonergic pathways. Brain Res 106: 257-269.

Gibbs MV, Thorpe JG (1983). Personality stereotype of noninstitutionalized Down syndrome children. Am J Ment Defic 87: 601-605.

Haw CM, Barnes TR, Clark K, Crichton P, Kohen D (1996). Movement disorder in Down's syndrome: a possible marker of the severity of mental handicap. Movement Disord 11: 395-403.

Hennessy MB, Foy T (1987). Nonedible material elicits chewing and reduces the plasma corticosterone response during novelty exposure in mice. Behav Neurosci 101: 237-245.

Hepper PG, Shahidullah S (1992). Habituation in normal and Down's syndrome fetuses. Q J Exp Psychol B 44: 305-317.
Hollander E, Rosen J (2000). Impulsivity. J Psychopharmacol 14(2 Suppl 1): S39-S44.

Huttunen HJ, Kuja-Panula J, Sorci G, Agneletti AL, Donato R, Rauvala H (2000). Coregulation of neurite outgrowth and cell survival by amphoterin and S100 proteins through receptor for advanced glycation end products (RAGE) activation. J Biol Chem 275: 40096-40105.

Kaneko WM, Ehlers CL, Philips EL, Riley EP (1996). Auditory event-related potentials in fetal alcohol syndrome and Down's syndrome children. Alcohol Clin Exp Res 20: 35-42.

Karrer JH, Karrer R, Bloom D, Chaney L, Davis R (1998). Eventrelated brain potentials during an extended visual recognition memory task depict delayed development of cerebral inhibitory processes among 6-month-old infants with Down syndrome. Int J Psychophysiol 29: 167-200.

Kato K, Suzuki F, Kurobe N, Okajima K, Ogasawara N, Nagaya M et al (1990). Enhancement of S-100 beta protein in blood of patients with Down's syndrome. J Mol Neurosci 2: 109-113.

Knieps LJ, Walden TA, Baxter A (1994). Affective expressions of toddlers with and without Down syndrome in a social referencing context. Am J Ment Retard 99: 301-312.

Kopp CB, Krakow JB, Johnson KL (1983). Strategy production by young Down syndrome children. Am J Ment Defic 88: 164-169.

La Malfa G, Notardi A, Hardoy MC, Bertelli M, Cabras PL (1997). Psychopathology and mental retardation: an Italian epidemiological study using the PIMRA. Res Dev Disabil 18: 179-184.

Liu JP, Lauder JM (1992). S-100 beta and insulin-like growth factor-II differentially regulate growth of developing serotonin and dopamine neurons in vitro. J Neurosci Res 33: 248-256.

Mazer C, Muneyyirci J, Taheny K, Raio N, Borella A, WhitakerAzmitia P (1997). Serotonin depletion during synaptogenesis leads to decreased synaptic density and learning deficits in the adult rat: a possible model of neurodevelopmental disorders with cognitive deficits. Brain Res 760: 68-73.

Myers BA, Pueschel SM (1991). Psychiatric disorders in persons with Down syndrome. J Nerv Ment Dis 179: 609-613.

Nygaard E, Smith L, Torgersen AM (2002). Temperament in children with Down syndrome and in prematurely born children. Scand J Psychol 43: 61-71.

Oquendo MA, Mann JJ (2000). The biology of impulsivity and suicidality. Psychiatr Clin N Am 23: 11-25.

Pueschel SM, Bernier JC, Pezzullo JC (1991). Behavioural observations in children with Down's syndrome. J Ment Defic Res 35: 502-511.

Roder JK, Roder JC, Gerlai R (1996). Memory and the effect of cold shock in the water maze in S100 beta transgenic mice. Physiol Behav 60: 611-615.

Royston MC, McKenzie JE, Gentleman SM, Sheng JG, Mann DM, Griffin WE et al (1999). Overexpression of s100beta in Down's syndrome: correlation with patient age and with beta-amyloid deposition. Neuropathol Appl Neurobiol 25: 387-393.

Schafer EW, Peeke HV (1982). Down syndrome individuals fail to habituate cortical evoked potentials. Am J Ment Defic 87: 332-337.

Schapiro MB, Haxby JV, Grady CL, Duara R, Schlageter NL, White $B$ et al (1987). Decline in cerebral glucose utilisation and cognitive function with aging in Down's syndrome. J Neurol Neurosurg Psychiatry 50: 766-774.

Seidl R, Kaehler ST, Prast H, Singewald N, Cairns N, Gratzer M et al (1999). Serotonin (5-HT) in brains of adult patients with Down syndrome. J Neural Transm Suppl 57: 221-232.

Takashima S, Iida K, Mito T, Arima M (1994). Dendritic and histochemical development and ageing in patients with Down's syndrome. J Intellect Disabil Res 38(Part 3): 265-273.

Tsuji M, Takeda, Matsumiya T (2000). Different effects of 5-HT1A receptor agonists and benzodiazepine anxiolytics on the emotional state of naive and stressed mice: a study using the hole-board test. Psychopharmacology (Berl) 152: 157-166. 
Whitaker-Azmitia PM (2001). Serotonin and brain development: role in human developmental diseases. Brain Res Bull 56: 479-485.

Whitaker-Azmitia PM, Wingate M, Borella A, Gerlai R, Roder J, Azmitia EC (1997). Transgenic mice overexpressing the neurotrophic factor S-100 beta show neuronal cytoskeletal and behavioral signs of altered aging processes: implications for Alzheimer's disease and Down's syndrome. Brain Res 776: 51-60.

Wilson CC, Faber KM, Haring JH (1998). Serotonin regulates synaptic connections in the dentate molecular layer of adult rats

via 5-HT1a receptors: evidence for a glial mechanism. Brain Res 782: 235-239.

Yan W, Wilson CC, Haring JH (1997). 5-HT1a receptors mediate the neurotrophic effect of serotonin on developing dentate granule cells. Brain Res Dev Brain Res 98: 185-190.

Yates CM, Simpson J, Gordon A (1986). Regional brain 5-hydroxytryptamine levels are reduced in senile Down's syndrome as in Alzheimer's disease. Neurosci Lett 65: 189-192. 